\title{
Estimating similarity in benthic communities over decades and in areas open and closed to fishing in the central Gulf of Maine, USA
}

\author{
Samuel C. Asci ${ }^{1,3, *}$, Richard W. Langton ${ }^{2}$, Kevin D. E. Stokesbury ${ }^{1}$ \\ ${ }^{1}$ School for Marine Science and Technology, University of Massachusetts Dartmouth, 836 South Rodney French Boulevard, \\ New Bedford, MA 02744, USA \\ ${ }^{2}$ Northeast Fisheries Science Center, Maine Field Station, 17 Godfrey Drive, Suite 1, Orono, ME 04473, USA \\ ${ }^{3}$ Present address: New England Fishery Management Council, 50 Water Street, Mill 2, Newburyport, MA 01950, USA
}

\begin{abstract}
The ledges and banks of the central Gulf of Maine (i.e. Fippennies Ledge, Jeffreys Ledge, Cashes Ledge, and Platts Bank) have supported groundfish and Atlantic sea scallop fisheries for centuries. The benthic community of Fippennies Ledge was evaluated and compared during 2 time periods separated by more than 2 decades, the first based on a series of photographs collected during manned submersible dives conducted in 1986 and 1987 and the second using photographs collected during drop camera video surveys conducted in 2009 to 2014. Further, Fippennies, Jeffreys, and Cashes ledges were permanently closed to fishing in 2002, while Platts Bank remained open, enabling a spatial comparison of benthic communities in open and closed areas along with the examination of changes in the benthos over the $28 \mathrm{yr}$ period on Fippennies Ledge. In the absence of commercial fishing, the scallop population on Fippennies Ledge appeared to be unchanged between 1986 and 2014, while observed differences in other dominant species were attributed to predator-prey relationships and long-term shifts in benthic conditions. Benthos of scallop habitat in the open and closed areas between 2009 and 2014 were similar in spatially dominant species composition and species richness, likely a result of the study area being a high-energy environment and therefore resilient to both natural and fishing perturbations. Understanding change in benthic communities over decades and between open and closed areas helps better define the dynamic nature of the central Gulf of Maine and may inform fisheries management in this region as the ocean climate changes.
\end{abstract}

KEY WORDS: Benthic imaging $\cdot$ Population dynamics $\cdot$ Placopecten magellanicus

\section{INTRODUCTION}

Mobile fishing gear (i.e. scallop dredges, beam trawls, otter trawls) can cause habitat degradation, specifically in sediment composition and benthic community structure, which can result in the reduction of benthic habitat complexity and affect trophic interactions (reviewed in Stewart \& Howarth 2016). Quantifying these fishing impacts is difficult, however, due to the minimal availability of control areas, where fishing is clearly restricted. This makes it diffi-

${ }^{*}$ Corresponding author: sasci@nefmc.org cult to estimate the degree of impact commercial fishing has on benthic communities as well as the recovery time for key species to return to their unfished abundance (Jennings \& Kaiser 1998, Sciberras et al. 2013, Stewart \& Howarth 2016).

Short-term and long-term area closures, or marine protected areas (MPAs), are effective tools as fisheries management moves from a single species- to an ecosystem-based approach that acknowledges the impacts of fishing on trophic interactions and benthic habitat conditions (Brodziak \& Link 2002, Link 2005, 
Stewart \& Howarth 2016). MPAs are created to protect and preserve resident target and non-target species as well as the benthic ecosystems which support their existence. Perhaps MPAs will offer an option as controls for studies on benthic perturbation, but generally such areas have been established for conservation rather than experimentation.

In July 1986 and June 1987, 8 dive transects were made on Fippennies Ledge, Gulf of Maine, USA, using the manned submersible 'Delta'. High-resolution photographic still frames of the seafloor taken during each dive were used to quantify mean densities of dominant benthic invertebrates in 1986 and again in 1987 after $1 \mathrm{yr}$ of heavy scallop fishing (Langton \& Robinson 1990). The dominant species, the Atlantic sea scallop Placopecten magellanicus, cerianthid anemone Cerianthus borealis, and sabellid myxicolid worm Myxicola infundibulum, declined significantly $(70 \%$ in scallops, 25 to $27 \%$ in cerianthids and myxicolids) between 1986 and 1987, suggesting that the benthic community was severely impacted by fishing operations (Langton \& Robinson 1990).

Fippennies Ledge, Jeffreys Ledge, Cashes Ledge, and Platts Bank were surveyed by the School for Marine Science and Technology (SMAST) using a drop camera in early August of 2009, 2010, 2011, 2013, and 2014 (henceforth denoted as 2009 to 2014). Three of the areas surveyed (Fippennies Ledge, Jeffreys Ledge, and Cashes Ledge) were closed to fishing as of 2002, while the fourth area surveyed (Platts Bank) remained open (Fig. 1). The initial 2009 survey investigated popular commercial fishing grounds that had been untargeted by the New Bedford scallop fleet since the mid-1980s to early 1990s. A strong recruitment of juvenile scallops was detected in both the 2009 (Stokesbury et al. 2010) and 2013 surveys (Asci 2016, Bethoney et al. 2016). In addition to estimating scallop density, abundance, and size distribution, the SMAST video survey characterizes the benthic habitat including densities per square meter of macroinvertebrates, spatial dominance of megafauna, and detailed information on substrate composition (Stokesbury 2002, Stokesbury et al. 2004, Stokesbury \& Harris 2006).

We hypothesize that the benthic community of Fippennies Ledge changed between 1987 and 2009 as a result of post-fishing recovery and factors other than fishing. The 2 benthic photographic surveys of Fippennies Ledge, in 1986 and 1987 and again from 2009 to 2014, presented an opportunity to determine if there was a change in the dominant invertebrate fauna over the past several decades.
We also hypothesize that the benthic communities in areas open and closed to scallop fishing in the central Gulf of Maine differed. Benthic communities in the open and closed areas, which were surveyed in the 2009-2014 period, were compared to examine impacts of continual commercial fishing.

These hypotheses were tested by comparing densities of the dominant invertebrate species and comparing biodiversity measures for the benthic communities. Langton \& Robinson (1990) monitored the dominant benthic invertebrate community of Fippennies Ledge over $2 \mathrm{yr}$, and Stokesbury et al. (2010) used $1 \mathrm{yr}$ of data to describe the scallop populations within the central Gulf of Maine. Using these studies as a foundation, we were able to synthesize the associated data sets, which are both based on measures per unit area from high-resolution photography, to extend this examination temporally and spatially on a scale few other studies have been able to achieve.

\section{MATERIALS AND METHODS}

\section{‘Delta' dive survey}

The 1986 and 1987 'Delta' dive transects on Fippennies Ledge covered from 1.9 to $3.7 \mathrm{~km}^{2}$ each, and 150 to 250 benthic photographs $(35 \mathrm{~mm})$ were collected per dive. Diver-scientists on board 'Delta' recorded observations of fauna, substrate type, and other information regarding the benthic habitat on a tape recorder. Photographs were examined on a light table; animals large enough to be resolved (2 to $5 \mathrm{~cm}$ ) were identified, and the number of individuals of each species category was recorded (Langton \& Robinson 1990). For this study, the original raw counts per photograph (1.24 $\mathrm{m}^{2}$ quadrat area) from the 1986 and 1987 'Delta' dives were analyzed to estimate the density per square meter of benthic invertebrates, where mean densities per square meter and SEs of the total sample were calculated using standard statistical methods summarized in Cochran (1977) and Krebs (1989), similar to the methods utilized by Langton \& Robinson (1990).

\section{SMAST video survey}

Observations of the benthic communities on Fippennies Ledge, Jeffreys Ledge, Cashes Ledge, and Platts Bank were made in 2009 to 2014 using the SMAST drop camera survey (Fig. 1). This survey employed a centric systematic sampling design, in 


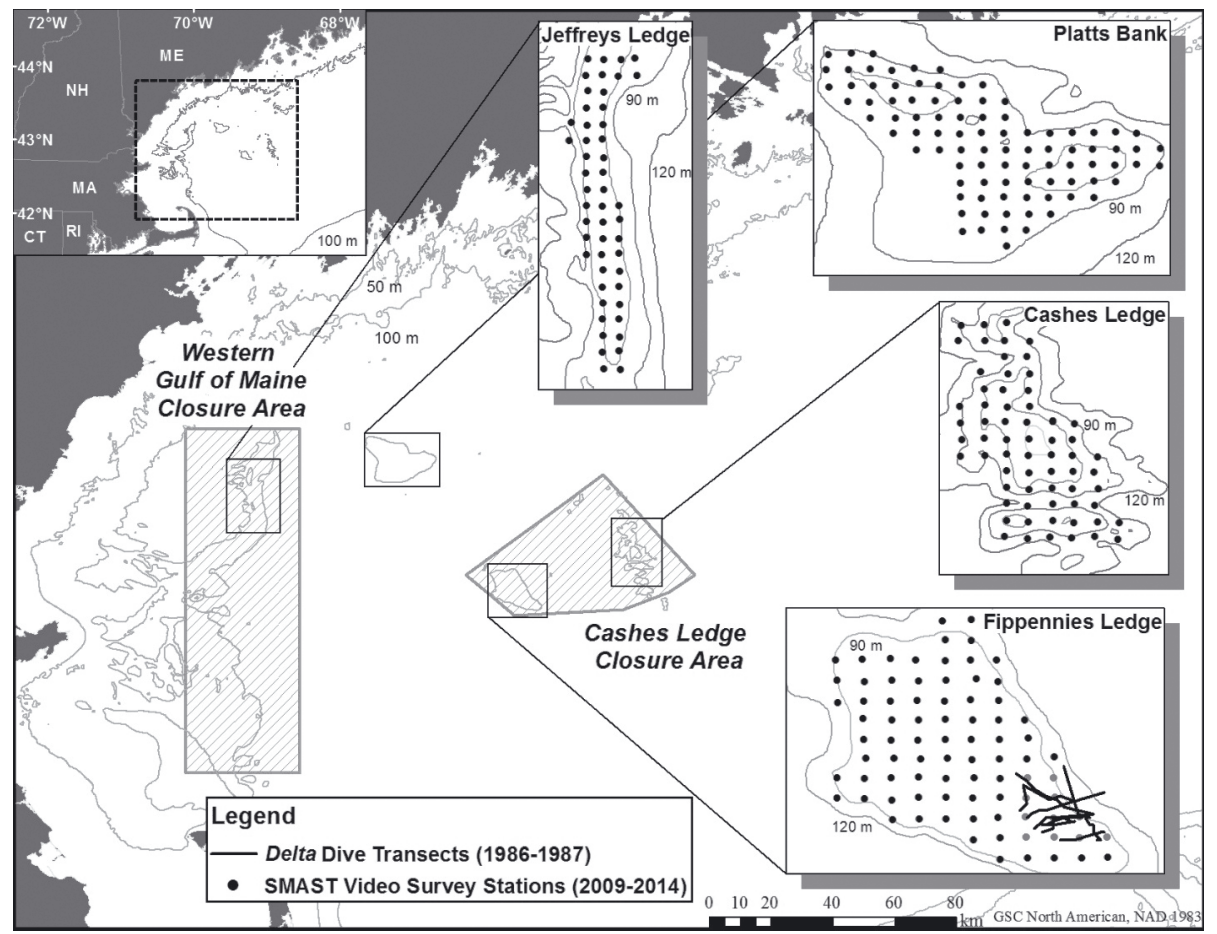

Fig. 1. Extent of the central Gulf of Maine study area. The Western Gulf of Maine Closure Area and Cashes Ledge Closure Area boundaries are shaded in grey. Also shown are the locations of 'Delta' dive transects from 1986 and 1987 (black lines) on Fippennies Ledge and School for Marine Science and Technology video survey stations (black dots) from 2009, 2010 2011, 2013, and 2014 on Fippennies Ledge, Jeffreys Ledge, Cashes Ledge, and Platts Bank

which the first station location was chosen randomly and subsequent stations were then located on a $1.0 \mathrm{~km}^{2}$ grid (Stokesbury et al. 2010). Upon arrival at each station, a commercial scallop fishing vessel deployed the drop camera pyramid system and as the vessel drifted, the pyramid was lowered to the sea floor and raised 4 times to collect 4 video quadrat samples separated by approximately $40 \mathrm{~m}$. To maintain the integrity of the sample design, the initial target station locations were the same each year. It is impossible, however, to drop the pyramid on exactly the same location of the sea floor each year due to current, wind, and the vessel's navigational ability; the vessel aims to begin within a $75 \mathrm{~m}$ radius of the target station location. The station depth ranged between 11 and $130 \mathrm{~m}$, but $95 \%$ of sampled stations were at depths between 25 and $100 \mathrm{~m}$, with an overall average of approximately $71 \mathrm{~m}$.

Fixed to the pyramid were 8 lights, 2 live-feed video cameras, and a high-resolution digital still camera (Carey \& Stokesbury 2011). Prior to surveying, the downward-facing live-feed cameras and high-resolution digital still camera were calibrated in a test tank to calculate lens height and quadrat size; the downward-facing live-feed cameras provided quadrat images of 2.84 and $0.60 \mathrm{~m}^{2}$, and the digital still camera provided high-resolution quadrat images of $1.04 \mathrm{~m}^{2}$ (Carey \& Stokesbury 2011). For density estimates of scallops on Fippennies Ledge, the quadrat sizes were increased based on the mean scallop shell height in the area to adjust for partially visible scallops counted along the edge of the image (Table 1) (O'Keefe et al. 2010).

Live video feed of the sea floor was recorded in the wheelhouse, and a custom computer field application allowed technicians to record station and quadrat number, date, time, latitude, longitude, depth, and number of scallops and other macroinvertebrates observed in each quadrat as well as substrate composition. Video recordings were later viewed in the

Table 1. Mean shell height of scallops observed on Fippennies Ledge and adjusted quadrat areas used to estimate scallop density in 2009, 2010, 2011, 2013, and 2014

\begin{tabular}{|ccc|}
\hline Year & $\begin{array}{c}\text { Mean shell } \\
\text { height }(\mathrm{mm})\end{array}$ & $\begin{array}{c}\text { Adjusted quadrat } \\
\text { area }\left(\mathrm{m}^{2}\right)\end{array}$ \\
\hline 2009 & 50.51 & 3.02 \\
2010 & 55.84 & 3.03 \\
2011 & 62.51 & 3.06 \\
2013 & 66.01 & 3.07 \\
2014 & 72.05 & 3.09 \\
\hline
\end{tabular}


laboratory, and a still image of each quadrat was analyzed. Sediments were visually identified from the video images following the Wentworth particle grade scale, where the sediment particle size categories were based on a doubling or halving of the fixed reference point of $1 \mathrm{~mm}$ : sand $=0.0625$ to $2.0 \mathrm{~mm}$, gravel $=>2.0$ to $256.0 \mathrm{~mm}$, and boulders = $>256.0 \mathrm{~mm}$ (Lincoln et al. 1992). Gravel was divided into 2 categories: granule/pebble $=>2.0$ to $64.0 \mathrm{~mm}$ and cobble $=>64.0$ to $256.0 \mathrm{~mm}$ (Lincoln et al. 1992, Stokesbury 2002, Harris \& Stokesbury 2010). Shell heights $(\mathrm{mm})$ of scallops completely within the image were measured from umbo to outer shell margin using ImagePro ${ }^{\circledR}$ image analysis software (Carey \& Stokesbury 2011). Density per square meter was calculated for scallops, anemones, sea stars, various other benthic invertebrates, and fish.

Mean densities and SEs of counted benthic invertebrates were calculated using equations for a 2stage sampling design (Cochran 1977, Krebs 1989, Stokesbury 2002, Carey \& Stokesbury 2011). This simplified version of the 2-stage variance is possible when the sampling fraction $\mathrm{n} / \mathrm{N}$ is small (Cochran 1977). This is the case for the video survey, where thousands of square meters are sampled compared to millions of square meters in the study area (Stokesbury \& Harris 2006). Sponges, hydrozoans/bryozoans, and sand dollars were recorded as present or absent within each quadrat (Stokesbury 2002, Stokesbury et al. 2004, Stokesbury \& Harris 2006).

Despite the 2-decade difference between the 'Delta' and SMAST collections, the field sampling methods and image quality of quadrat still frames were similar (Fig. 2), allowing for the benthic invertebrate species to be quantified on the same spatial scale (i.e. ind. $\mathrm{m}^{-2}$ ). It was therefore possible to compare density per square meter estimates of the dominant benthic invertebrate species observed in 1986 and 1987 (Fig. 3) on Fippennies Ledge with the more recent density estimates from 2009 to 2014. Significant shifts in density were tested using a 1 -way ANOVA $(\alpha=0.05)$ over the duration of survey years, and then a Tukey post hoc $(\alpha=0.05)$ test was employed if significant differences were noted. This comparison was repeated excluding estimates from 1987, as appreciable dredging had occurred that year (Langton \& Robinson 1990). Comparing density per square meter of Atlantic sea scallops Placopecten magellanicus, cerianthid anemones Cerianthus borealis, sea stars Asterias spp., and sabellid myxicolid worms Myxicola infundibulum, among each of the 7 years Fippennies Ledge was surveyed, as well as the 6 years where no commercial fishing occurred, provided statistical evi-

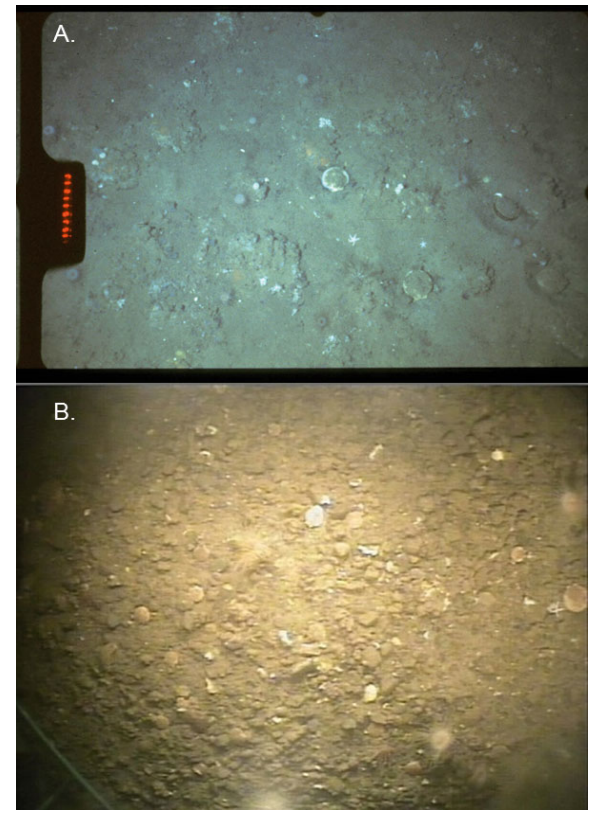

Fig. 2. Example of quadrat still frames used to characterize the benthic community of Fippennies Ledge between the (A) 1986 and 1987 'Delta' dive surveys and (B) 2009, 2010, 2011, 2013, and 2014 School for Marine Science and Technology drop camera surveys. Note that 'Delta' images (A) included a time-stamp on the left side of the quadrat

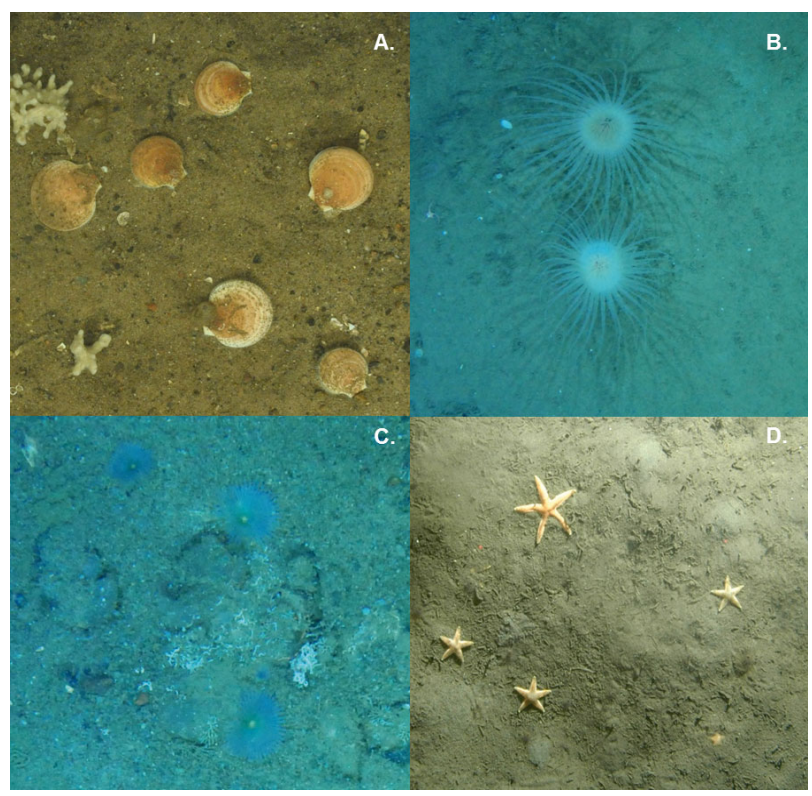

Fig. 3. Digital still images of the dominant invertebrate species on Fippennies Ledge. (A) Atlantic sea scallop Placopecten magellanicus, (B) cerianthid anemone Cerianthus borealis, (C) myxicolid worm Myxicola infundibulum, (D) northern sea star Asterias vulgaris. The combination of a high-resolution camera and light-emitting diode lighting is required to accurately identify $M$. infundibulum; this combination was only used in the 2009 School for Marine Science and Technology video survey 
dence of changes in benthic community structure on a scale of almost 3 decades. The SMAST drop camera samples for each year (2009 to 2014) were treated as independent due to the variation in vessel positioning at each station and the effect of 1 yr between surveying the benthic community; many of these species are annual, winter storms in this area are severe, and tidal currents are strong, causing shifts in sea floor structure (Thompson 2010). Comparing scallop size distributions between 1986-1987 and 2009-2014 was not possible because 'Delta' surveys did not measure scallops.

The SMAST video surveys covered areas both opened and closed to fishing; stations surveyed on Fippennies Ledge, Jeffreys Ledge, and Cashes Ledge fell within the boundaries of the Western Gulf of Maine Closure Area and Cashes Ledge Closure Area, while the surveyed area on Platts Bank was not closed to fishing (Fig. 1). A preliminary test of independence was performed to determine if substrate composition differed between areas (chi-square, $\alpha=$ 0.05). At each station, the most abundant coarse substrate type (i.e. sand, gravel, cobble, rock) was determined (Harris \& Stokesbury 2010). Then, data were compiled by area for all years surveyed by SMAST and statistically compared. To reduce uncertainty in the scenario where substrate composition varied significantly between areas, analysis was conducted using only stations that were representative of suitable scallop habitat; this allowed for comparisons of the total area surveyed to be made, as well as comparisons of scallop habitat within each respective area.

Scallops aggregate in areas with coarse sandgranule-pebble substrate (Langton \& Robinson 1990, Thouzeau et al. 1991, Stokesbury 2002, Stokesbury \& Harris 2006). These areas are known to fishermen, and are where the majority of fishing effort is directed, although fishing effort will shift if the scallops are below exploitable size. Therefore, a comparison between scallop substrates within the closed and open areas not only captures the highest areas of impact but also reduces the effect of different substrates on benthic community structure, since the substrates analyzed are homogeneous. The drop camera survey was designed to define exploitable scallop beds, and 1 scallop station ${ }^{-1}$ is roughly a minimal commercial density; therefore, a station with 1 or more scallops represents suitable scallop habitat (Stokesbury 2002).

A percent similarity index (Renkonen 1938) was used to measure similarity between benthic community structures of the open and closed areas over the entirety of the survey period, in both total habitat and scallop habitat. This index compared relative proportions of taxonomic categories present in each area, where relative proportions were standardized as a percentage of the total categories observed. The percentage similarity ranges from $100 \%$ for very similar communities to $0 \%$ for those that are completely different. Although straightforward, this percent similarity index is robust to sample size and species diversity (Krebs 1989) and serves as a quantitative coefficient of community structure (Stokesbury \& Harris 2006). The percent similarity index uses species occurrence (standardized by quadrat) as opposed to abundance (no. of ind. station ${ }^{-1}$ ), which means the spatial dominance of species categories was compared as opposed to the true number of individuals observed. This allowed for a more comprehensive model of the benthic communities, as rarer species were not completely excluded due to the extraordinarily high abundance of the few dominant species. The percent similarity index included only species that are sessile or exhibit locally mobile behavior. Though the SMAST drop camera survey has the ability to identify highly mobile species, it is designed to observe sessile and locally mobile species (MacDonald et al. 2010); consequently, it is possible that observations (or lack thereof) of highly mobile species (i.e. roundfish, flatfish, and other demersal fish) would misrepresent the actual abundance of such species in any given quadrat.

The frequency of species present at each station was used as a metric of species richness (Krebs 1989); estimates of species richness were calculated for each area, and then open and closed areas were compared statistically. Because this richness measure was broad and designed to encompass as many species categories as possible, all species identifiable by the SMAST video survey were included. All years of data were compiled by specific area, and the frequency of species present at each station was recorded. Observed species frequencies per station were compared using a 2-sample KolmogorovSmirnov test, where the test statistic critical level was adjusted to the number of collective samples (total stations surveyed) for each area (Siegel \& Castellan 1988). Cumulative frequency distributions of number of species observed per station were plotted, and sample mean $(\bar{x}), \operatorname{SE}(\bar{x})$, and mode (Mo) were calculated to further compare open and closed areas.

Rarefaction, an estimation of expected species richness based on the number of individuals sampled, was employed to further compare benthic 
invertebrate communities. For each area, counts of individuals observed per station were compiled by species, and rarefaction curves were produced using the $\mathrm{R}$ package vegan (Oksanen et al. 2008). Because this method estimates the expected number of species observed as a function of individuals sampled, rarefaction curves included only benthic invertebrate species which were counted by the drop camera survey (i.e. scallops, sea stars, crabs, hermit crabs, whelks, lobsters, moon snails, sea mice).

A test of heterogeneity was employed which compared frequencies of quantifiable species observed by the SMAST video survey between the open and closed areas. The counts of individual species observed were combined for all years surveyed by each area, and compared using chi-square $(\alpha=0.05)$. To avoid violating chi-square assumptions, species frequencies were grouped so that $<20 \%$ of expected values were $<5$ (Stokesbury 2002, Zar 2010).

\section{RESULTS}

'Delta' dive (1986 to 1987$)$ survey coverage $\left(\sim 10 \mathrm{~km}^{2}\right)$ was limited to the southeastern part of Fippennies Ledge, whereas SMAST drop camera (2009 to 2014) survey coverage $\left(\sim 83 \mathrm{~km}^{2}\right)$ encompassed the entirety of Fippennies Ledge (Fig. 1). Despite the relatively small area where these surveys overlapped, comparing 'Delta' (1986 to 1987) observations to SMAST (2009 to 2014) observations was valid because of the uniform nature of this area, including characteristics such as depth, substrate composition, and distribution of dominant benthic invertebrates. Post hoc analysis (1-way ANOVA, $\alpha=0.05$ ) comparing observations from SMAST stations inside $(\mathrm{n}=38)$ vs. outside $(\mathrm{n}=376)$ the survey coverage of 'Delta' dives showed no significant variation in densities per square meter of scallops $\left(F_{(1,412)}=\right.$ $0.215, \mathrm{p}=0.643)$, anemones $\left(F_{(1,412)}=0.016\right.$, $\mathrm{p}=0.899)$, and sea stars $\left(F_{(1,412)}=0.189, \mathrm{p}=\right.$ 0.664 ), confirming the uniform distribution of these species across Fippennies. Restricting analysis to include only SMAST stations (2009 to 2014) within the survey area of 'Delta' dives (1986 to 1987) severely reduces sample size. This was highlighted by the already minimal myxicolid SMAST data available (only 2009, $\mathrm{n}=81$ ). Post hoc analysis (1-way ANOVA, $\alpha=0.05$ ) comparing observations from SMAST stations inside $(n=8)$ vs. outside $(n=73)$ the survey coverage of 'Delta' dives confirmed no significant variation in myxicolid density per square meter $\left(F_{(1,79)}=2.437, \mathrm{p}=0.122\right)$; however, the decreased sample size greatly reduced statistical power $(0.22)$ of the test below the desired threshold $(0.80)$. Due to the uniform nature of Fippennies Ledge and associated statistical consequence in reducing sample size, analysis and subsequent findings incorporated all available 'Delta' (1986 to 1987) and SMAST (2009 to 2014) survey data.

Densities per square meter of the dominant benthic invertebrates (Table 2) on Fippennies Ledge were significantly different between 1986-1987 and 20092014 for scallops $\left(F_{(6,1833)}=34.506, \mathrm{p}=<0.001\right)$, anemones $\left(F_{(6,1833)}=58.267, \mathrm{p}=<0.001\right)$, sea stars $\left(F_{(6,1833)}\right.$ $=7.389, \mathrm{p}=<0.001)$, and myxicolids $\left(F_{(2,1502)}=7.317\right.$, $\mathrm{p}=<0.001$ ). Post hoc Tukey analysis identified scallop density in 1987 to be different from 1986 and 2009-2014 and showed that 1986 was different than 2010, 2011, 2013, and 2014. Anemone density differed between 1986 and 1987 and was different between 1986-1987 and 2009-2014. Sea star density differed between 2014 and 1986-2013. Myxicolid density differed between 1986-1987 and 2009.

Comparisons of Fippennies Ledge over time, excluding the year of heavy fishing (1987), also showed significant differences in densities per square meter of scallops $\left(F_{(5,845)}=4.122, \mathrm{p}=0.001\right)$, anemones $\left(F_{(5,845)}=67.836, \mathrm{p}=<0.001\right)$, sea stars $\left(F_{(5,845)}=\right.$ $10.578, \mathrm{p}=<0.001)$, and myxicolids $\left(F_{(1,514)}=8.675\right.$, $\mathrm{p}=0.003)$. Post hoc Tukey results for anemone, sea star, and myxicolid density were the same as the previous analysis, which included the fished year; however, unlike previous analyses including the fished year, scallop density was only different between 1986 and 2014.

Scallops, anemones, and sea stars were the dominant benthic invertebrates on Fippennies Ledge

Table 2. Density $\left(\mathrm{m}^{-2}\right.$, mean $\left.\pm \mathrm{SE}\right)$ of scallops, anemones, sea stars, and myxicolids based on observations made during 'Delta' dives (1986 and 1987) and the School for Marine Science and Technology video survey $(2009,2010,2011,2013$, and 2014) on Fippennies Ledge. Myxicolid estimates were not available (n/a) after 2009

\begin{tabular}{|cccccc|}
\hline Year & $\mathrm{n}$ & Scallops & Anemones & Sea stars & Myxicolids \\
\hline 1986 & 435 & $1.04 \pm 0.11$ & $1.80 \pm 0.09$ & $0.24 \pm 0.03$ & $3.41 \pm 0.34$ \\
1987 & 989 & $0.32 \pm 0.02$ & $1.48 \pm 0.05$ & $0.19 \pm 0.02$ & $3.29 \pm 0.13$ \\
2009 & 81 & $1.39 \pm 0.24$ & $0.05 \pm 0.02$ & $0.12 \pm 0.03$ & $1.10 \pm 0.20$ \\
2010 & 84 & $1.70 \pm 0.33$ & $0.10 \pm 0.03$ & $0.06 \pm 0.01$ & $\mathrm{n} / \mathrm{a}$ \\
2011 & 83 & $1.75 \pm 0.34$ & $0.06 \pm 0.03$ & $0.05 \pm 0.01$ & $\mathrm{n} / \mathrm{a}$ \\
2013 & 84 & $1.66 \pm 0.28$ & $0.03 \pm 0.01$ & $0.16 \pm 0.02$ & $\mathrm{n} / \mathrm{a}$ \\
2014 & 84 & $2.16 \pm 0.29$ & $0.09 \pm 0.02$ & $0.51 \pm 0.08$ & $\mathrm{n} / \mathrm{a}$ \\
\hline
\end{tabular}


Table 3. Percent similarity index comparing species categories present in the open and closed areas using all stations surveyed by the School for Marine Science and Technology. Lines indicate areas used to calculate the percent similarity index

\begin{tabular}{|c|c|c|c|c|}
\hline \multirow[t]{2}{*}{ Species category } & \multicolumn{3}{|c|}{ Total habitat } & \multirow{2}{*}{$\begin{array}{l}\text { Open } \\
\text { Platts }\end{array}$} \\
\hline & Fippennies & Jeffreys & Cashes & \\
\hline Scallops & 31.9 & 33.4 & 6.0 & 20.2 \\
\hline Sea stars & 27.6 & 31.0 & 42.6 & 37.2 \\
\hline Crabs & 0.3 & 1.1 & 2.1 & 5.3 \\
\hline Hermit crabs & 2.1 & 0.6 & 0.5 & 1.1 \\
\hline Lobsters & 0.1 & 0.0 & 0.4 & 0.5 \\
\hline Whelks & 1.3 & 0.4 & 0.0 & 1.5 \\
\hline Moon snails & 0.0 & 0.2 & 0.0 & 0.2 \\
\hline Sea mice & 0.1 & 0.0 & 0.0 & 0.0 \\
\hline Skates & 0.1 & 0.4 & 0.5 & 0.6 \\
\hline Sand dollars & 0.5 & 2.2 & 0.5 & 1.1 \\
\hline Bryz./Hydr. & 13.2 & 7.3 & 12.5 & 10.5 \\
\hline Sponges & 22.9 & 23.3 & 34.8 & 21.7 \\
\hline \multirow[t]{5}{*}{$\%$ similarity } & 91.7 & & & \\
\hline & 70.6 & & & \\
\hline & 83.4 & & & \\
\hline & & 70.2 & & \\
\hline & & 84.2 & 79.5 & \\
\hline
\end{tabular}

between 2009 and 2014. No variation in density per square meter was apparent for scallops $\left(F_{(4,411)}=\right.$ $0.855, \mathrm{p}=0.491)$ and anemones $\left(F_{(4,411)}=1.542, \mathrm{p}=\right.$ 0.188 ); however, sea star density per square meter did vary significantly $\left(F_{(4,411)}=22.734, \mathrm{p}=<0.001\right)$. Tukey post hoc analysis identified sea star density in 2014 as being significantly higher than in 2009 to 2013.

In the open vs. closed area comparison, Fippennies, Jeffreys, and Platts had similar benthic community structures when all stations were examined (Table 3). Of the 12 species categories considered, scallops $(31.9,33.4$, and $20.2 \%)$ and sea stars $(27.6$, 31.0 , and $37.2 \%$ ) dominated these respective areas. Cashes was the least similar to the other closed areas (70.6\% with Fippennies, $70.2 \%$ with Jeffreys) and slightly more similar with the open area, Platts $(79.5 \%)$. Cashes had minimal scallop composition $(6.0 \%)$ and was dominated by sea stars $(42.6 \%)$ and sponges $(34.8 \%)$. Fippennies and Jeffreys had the most similar benthic communities $(91.7 \%)$.

Substrate composition varied significantly between areas $\left(\chi^{2}{ }_{(9, \mathrm{~N}=1460)}=47.51, \mathrm{p}<0.001\right)$; therefore, the percent similarity index was used to compare benthic community structure of scallop habitat between areas. Within scallop habitat, Fippennies, Jeffreys, Cashes, and Platts all had highly similar benthic community structures (Table 4). Of the 11 species categories con-
Table 4. Percent similarity index comparing species categories present in the open and closed areas using only stations defined as scallop habitat. Lines indicate areas used to calculate the percent similarity index

\begin{tabular}{|c|c|c|c|c|}
\hline \multirow[t]{2}{*}{ Species category } & \multicolumn{3}{|c|}{ Scallop habitat } & \multirow{2}{*}{$\begin{array}{l}\text { Open } \\
\text { Platts }\end{array}$} \\
\hline & Fippennies & Jeffreys & Cashes & \\
\hline Sea stars & 40.5 & 46.6 & 45.3 & 46.7 \\
\hline Crabs & 0.5 & 1.6 & 2.3 & 6.7 \\
\hline Hermit crabs & 3.0 & 1.0 & 0.6 & 1.4 \\
\hline Lobsters & 0.2 & 0.0 & 0.4 & 0.6 \\
\hline Whelks & 1.8 & 0.6 & 0.0 & 1.8 \\
\hline Moon snails & 0.0 & 0.3 & 0.0 & 0.3 \\
\hline Sea mice & 0.2 & 0.0 & 0.0 & 0.0 \\
\hline Skates & 0.2 & 0.6 & 0.6 & 0.8 \\
\hline Sand dollars & 0.7 & 3.2 & 0.6 & 1.4 \\
\hline Bryz./Hydr. & 19.4 & 11.0 & 13.3 & 13.2 \\
\hline Sponges & 33.6 & 35.0 & 37.0 & 27.2 \\
\hline \multirow[t]{5}{*}{$\%$ similarity } & 88.0 & & & \\
\hline & 89.4 & & & \\
\hline & 85.6 & & & \\
\hline & & 94.6 & & \\
\hline & & 90.0 & & \\
\hline
\end{tabular}

sidered (scallops were removed), sea stars $(40.5,46.6$, 45.3 , and $46.7 \%$ ) and sponges (33.6, 35.0, 37.0, $27.2 \%)$ dominated these respective areas. Scallop habitat on Jeffreys and Cashes had the highest similarity between benthic community structures (94.6\%), while Fippennies and Platts had the least similar benthic community structures (85.6\%).

Species richness cumulative frequency distribution curves were similar across all areas (Fig. 4), with only Jeffreys and Platts being significantly different $\left(D_{(227,454)}=0.11, \mathrm{p}<0.001\right)$. Of the 45 species identifiable by the SMAST video survey, 36 were seen on Platts, 34 were seen on Fippennies, 33 were seen on Cashes, and 29 were seen on Jeffreys. Platts had the highest ranked mean number of species observed per station $(\bar{x}=3.54 \pm 0.07)$ but was only slightly greater than second highest ranked Cashes $(\bar{x}=3.43 \pm 0.08)$. Jeffreys, Cashes, and Platts all shared the same number of species per station mode (3), where Fippennies showed a slightly higher mode (4). Rarefaction analysis of benthic invertebrate species suggested species richness was highest on Platts, followed by Jeffreys, Cashes, and Fippennies (Fig. 5). Of the 8 species included in the analysis, 8 were observed on Platts and Fippennies, 7 were observed on Jeffreys, and 6 were observed on Cashes. The number of individual benthic invertebrates sampled was greatest on Fippennies (approximately 10000 ind.), followed by 


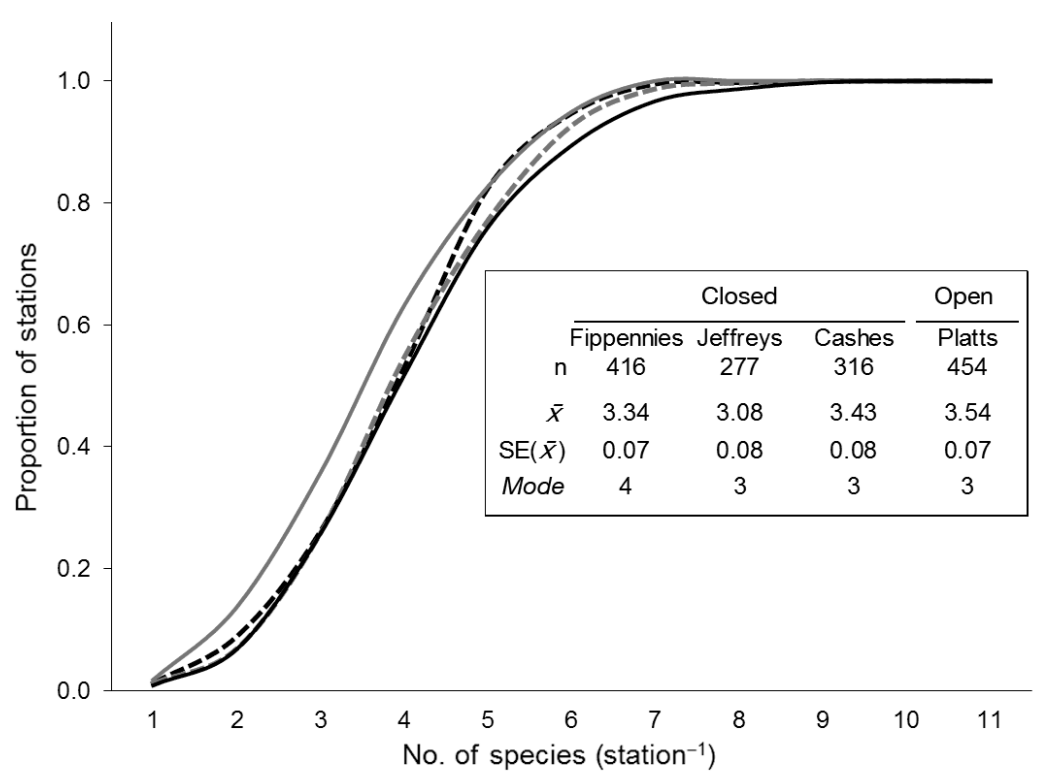

Fig. 4. Cumulative frequency distribution species richness curves of the number of species observed per station vs. the proportion of total stations (n) for the area. Platts Bank is the solid black line, Fippennies Ledge is the dashed black line, Jeffreys Ledge is the solid grey line, and Cashes Ledge is the dashed grey line

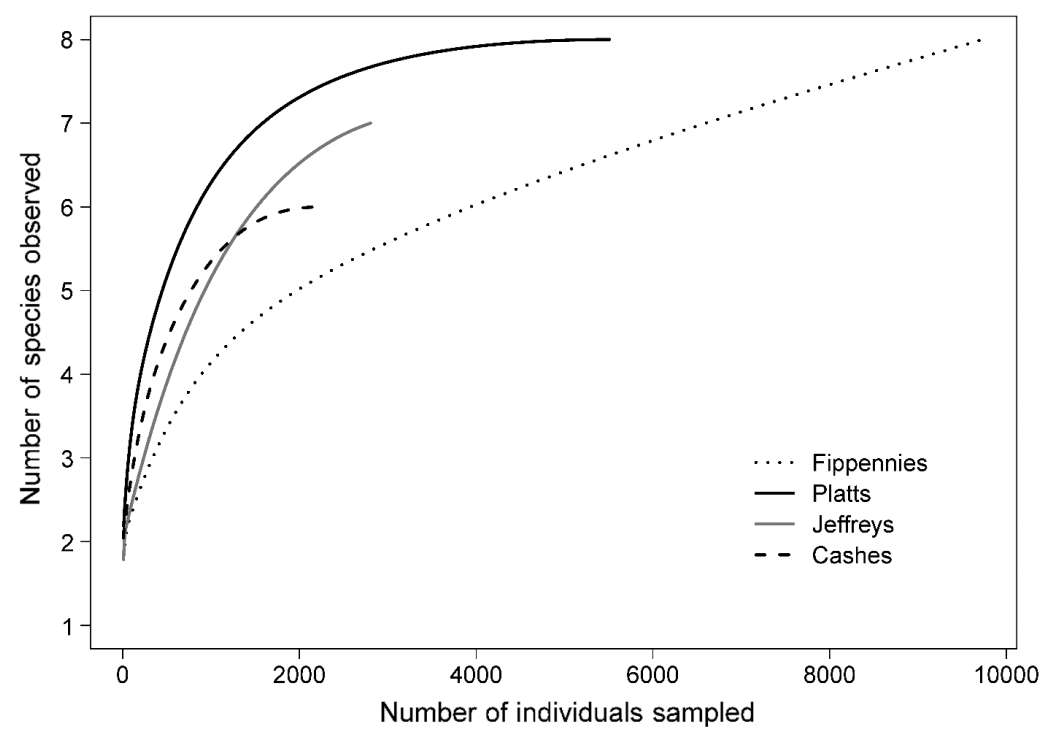

Fig. 5. Rarefaction curves comparing the number of benthic invertebrate species observed based on the total number of individuals sampled

Platts (approximately 6000 ind.), and was roughly similar on Jeffreys (approximately 3000 ind.) and Cashes (approximately 2500 ind.).

Grouped species frequencies were significantly different among all 4 areas $\left(\chi_{(18,22474)}^{2}=3434.9, \mathrm{p}<\right.$ 0.001) (Table 5). Expected grouped species frequencies were determined for each area, affording the opportunity to compare differences between observed and expected frequencies; the number of individuals expected to exist in a given area was based on the number of individuals observed across the entire study region as a function of the size of the specific area. The difference between observed and expected values indicated more scallops on Fippennies and Jeffreys than expected and fewer scallops on Cashes and Platts than expected. There were fewer sea stars on Fippennies and Jeffreys and more sea stars on Cashes and Platts than expected. Cashes Ledge had more bryozoans/hydrozoans and sponges, while the other 3 areas had fewer bryozoans/hydrozoans than expected.

\section{DISCUSSION}

Seldom in marine ecology is there the opportunity to examine temporally distinct generations of the benthic invertebrate community of an offshore ledge using comparable sampling units. Here, the Fippennies Ledge macrobenthic community separated by 28 yr was compared. Given this extended time period, the minimal variation in scallop density per square meter between the unfished years was striking. The fishing effort for this area is unknown before 1986 and between 1988 and 2002, but after 2002 the area was closed to fishing. This suggests a stable population structure for scallops occurred shortly after the Cashes Ledge Closure Area was established. The benthos of heavily fished areas can take over 10 yr to fully recover (Collie et al. 2000, 2009, Lambert et al. 2014), whereas populations of relatively fast-growing species with high fecundity, such as scallop populations on Georges Bank, have appeared to recover in $<5$ yr (Stokesbury 2002). Our findings suggest the scallop population on Fippennies recovered in $<8$ yr. At least 2 factors affect the stability of the population structure of scallops on Fippennies Ledge and contribute to the postfishing recovery: (1) a reduction of fishing effort through the establishment of closures, and (2) extreme recruitment events, of which 2 were observed between 2009 and 2014 (Stokesbury et al. 2010, Bethoney et al. 2016). 
Table 5. Observed and expected grouped species frequencies of the open (Platts) and closed (Fippennies, Jeffreys, Cashes) areas including chi-square results

\begin{tabular}{|lcccc|}
\hline & \multicolumn{1}{c}{ Fippennies } & Jeffreys & Cashes & Platts \\
\hline $\mathrm{n}$ & 416 & 277 & 316 & 454 \\
Scallops & & & & \\
Observed & 8828 & 2438 & 990 & 4107 \\
Expected & 7593 & 2239 & 2127 & 4403 \\
Sea stars & & & & \\
Observed & 867 & 354 & 1240 & 1291 \\
Expected & 1741 & 513 & 488 & 1010 \\
Crustaceans & & & & \\
Observed & 22 & 8 & 18 & 91 \\
Expected & 65 & 19 & 18 & 37 \\
Gastropods & & & & \\
Observed & 12 & 2 & 1 & 13 \\
Expected & 13 & 4 & 4 & 8 \\
Sand dollars & & & & \\
Observed & 4 & 10 & 3 & 11 \\
Expected & 13 & 4 & 4 & 8 \\
Bryozoans/hydrozoans & & & & \\
Observed & 262 & 51 & 131 & 159 \\
Expected & 280 & 83 & 78 & 162 \\
Sponges & & & & \\
Observed & 434 & 212 & 539 & 376 \\
Expected & 724 & 214 & 203 & 420 \\
& & & & \\
& & & $\chi^{2}$ & 3434.9 \\
& & & $\mathrm{~d} f$ & $<0.001$ \\
$\alpha=0.05$ & & & & \\
\hline
\end{tabular}

Between 1986-1987 and 2009-2014, anemone and myxicolid density per square meter decreased 67 and $95 \%$, respectively, in sharp contrast to the stability of the scallop population. As Fippennies Ledge had not been fished since 2002, and in accordance with the 10 yr recovery time horizon (Collie et al. 1997, 2009, Lambert et al. 2014), it is unlikely that long-term effects of commercial dredging prevented these species from recovering. Anemones and myxicolids potentially feed on scallop larvae (Shumway et al. 1985, 1988, Langton \& Robinson 1990), and scallop larvae were clearly abundant given the 2009 and 2013 recruitment events (Stokesbury et al. 2010, Asci 2016, Bethoney et al. 2016); therefore, food availability was most likely not limiting. Other factors, such as the Gulf of Maine water temperature increasing more rapidly in the past decade than in other regions globally (Pershing et al. 2015), may be driving a shift in the benthic community, for example, and therefore impacting or even redefining what constitutes a recovery.

The marked increase of sea stars between 2013 and $2014(\bar{X}=0.16 \pm 0.02$ to $\bar{X}=0.51 \pm 0.08)$ correlated with high scallop abundance on Fippennies in 2014 $\left(\approx 1.81 \times 10^{8}\right.$ ind.). Sea stars are a major predator of scallops, particularly smaller juvenile scallops (Marino et al. 2007); sea stars respond to increased prey abundance by increasing individual consumption rates and by increasing in number (Barbeau \& Scheibling 1994, Barbeau et al. 1996, Marino et al. 2007), and they tend to aggregate in high density in closed areas (Marino et al. 2007). Interestingly, Platts Bank, the one continuously open area, had fewer scallops than expected but a higher concentration of sea stars (Table 5). This is possibly due to the scallop predator-prey relationship, and may relate directly to fishing activity; commercial catch is processed at sea, where scallops are shucked for their adductor muscle and all other body parts are discarded overboard, which in turn may attract starfish, as do high densities of juvenile scallops (Langton \& Bowman 1980, Caddy 1989, Orensanz et al. 1991, Barbeau et al. 1996, Marino et al. 2007).

No direct relationship between benthic community structure and commercial fishing was apparent. Fippennies, Jeffreys, and Platts had the highest percent similarity, and were only different in the ranking of the most spatially dominant species; scallops were more spatially dominant than sea stars on Fippennies and Jeffreys, and sea stars were more spatially dominant than scallops on Platts. Fippennies and Jeffreys had more scallops observed than expected and fewer sea stars observed than expected; Platts had fewer scallops than expected and more sea stars. Cashes was the outlier; bryozoans/hydrozoans and sponges were spatially more dominant than scallops, and were also observed more frequently than expected, reflecting the difference in substrate composition between Cashes and the other areas, as these species inhabit bouldered areas which are common on Cashes (Bell \& Barnes 2003, Brusca \& Brusca 2003, Weaver et al. 2007, Bell 2008). When benthic community structures of scallop habitat (assumed to have homogeneous substrate across areas) were compared, each area was highly similar, further suggesting that overall variation in benthic community structure between areas was dependent on substrate as opposed to fishing intensity.

Species richness and commercial fishing intensity were unrelated. Besides Jeffreys and Platts, cumulative frequency distributions of species observed per station were similar. Descriptive statistics for each area showed only slight differences between greatest and least sample mean (0.46 species station ${ }^{-1}$ ) and mode (1.0 species station $\left.{ }^{-1}\right)$. Large differences in sample sizes, in particular for Jeffreys $(n=277)$ and 
Platts $(\mathrm{n}=454)$, reflect a common problem encountered with biodiversity measures. Increasing number of observed species correlates directly with an increasing sample size (Krebs 1989, Chao et al. 2005, Colwell 2009, Gotelli \& Colwell 2011); this phenomenon most likely explains why cumulative frequency distributions of Jeffreys and Platts were found to be significantly different. This point is illustrated when comparing expected species richness based on the number of individuals sampled (i.e. rarefaction curves) of benthic invertebrate species across the survey areas. For example, there were twice as many individuals observed on Platts as on Jeffreys, yet only one less species was observed on Jeffreys compared to Platts. Furthermore, Platts and Jeffreys rarefaction curves followed a similar slope, suggesting that increased sampling on Jeffreys may have led to an increase in species observed.

Fishing impact was not great enough to noticeably alter the benthic community of Platts Bank. This is either because minimal fishing occurred on Platts Bank during the survey period or because the benthic community of Platts Bank is very resilient. The first scenario is unlikely; Platts is a favored target of commercial scallop fleets, both of which have been rising in ex-vessel value and annual landings for several years. The second scenario, however, is the more likely explanation; fished benthic communities which experience high natural disturbance are very similar to unfished areas with high natural disturbance (Hiddink et al. 2006, Sciberras et al. 2013, van Denderen et al. 2015), suggesting that certain benthic communities are more resilient to fishing activity (Stokesbury \& Harris 2006, Diesing et al. 2013, Szostek et al. 2016).

Benthic communities are both complex and diverse, and vary in disturbance recovery times; the post-fishing megafaunal community of the offshore region of the northeastern USA, for example, may take up to $10 \mathrm{yr}$ to fully recover (Collie et al. 1997, Lambert et al. 2014). However, the diversity in sediment types and other environmental drivers that exist throughout the Gulf of Maine region defy a general characterization in terms of how a specific ledge or bank responds to fishing perturbations. In the case of our study area, the central Gulf of Maine, sediment types are generally more coarse, which reflects the complex oceanography and tidal structure in this region (Townsend et al. 2006) and suggests that it is a highenergy environment, and is subject to strong wave action and currents. Because these ledges and banks likely withstand strong natural perturbation, they may be more resilient to fishing than the surrounding deep muddy basins, for example, depending of course on the frequency and intensity of fishing. Our monitoring of the sea floor found an unchanged scallop population after roughly 2 decades, and described great similarity between an evidently resilient fished benthic community and its unfished analogs within the central Gulf of Maine. Thus, we must consider the possibility that commercial scallop fishing is not detrimental to the overall benthic community of this high-energy environment, and that the central Gulf of Maine is capable of maintaining a healthy macrobenthic community over decadal time scales.

Acknowledgements. We thank W. Robinson, I. Babb, and P. Auster for their great contributions to the 'Delta' dive program and to the content of the work done here. Thanks to the students, staff, captains, and crews that sailed on the SMAST research trips. Special thanks to scallop fishing vessel owner-captains D. Eilertsen and M. Vieira for their unwavering support of this largely unfunded project. Thanks to T. Jaffarian for the development of the SMAST survey software and database. Thanks to G. Fay for his contributing role as a Master's thesis committee member and for refining the original work this research was based on. Partial funding was provided by NOAA Sea Scallop Research Set-Aside Program NA10NMF4540474. The views expressed in this paper are the authors', and do not necessarily reflect the views of NOAA.

\section{LITERATURE CITED}

Asci SC (2016) Estimating similarity in benthic communities of open and closed areas in the central Gulf of Maine, focusing on sea scallop mortality. MS thesis, University of Massachusetts, Dartmouth, MA

Barbeau MA, Scheibling RE (1994) Behavioral mechanisms of prey size selection by sea stars (Asterias vulgaris Verrill) and crabs (Cancer irroratus Say) preying on juvenile sea scallops (Placopecten magellanicus (Gmelin)). J Exp Mar Biol Ecol 180:103-135

* Barbeau MA, Hatcher BG, Scheibling RE, Hennigar AW, Taylor LH, Risk AC (1996) Dynamics of juvenile sea scallop (Placopecten magellanicus) and their predators in bottom seeding trials in Lunenburg Bay, Nova Scotia. Can J Fish Aquat Sci 53:2494-2512

Bell JJ (2008) The functional roles of marine sponges. Estuar Coast Shelf Sci 79:341-353

Bell JJ, Barnes DK (2003) The importance of competitor identity, morphology and ranking methodology to outcomes in interference competition between sponges. Mar Biol 143:415-426

Bethoney ND, Asci S, Stokesbury KDE (2016) Implications of extremely high recruitment events into the US sea scallop fishery. Mar Ecol Prog Ser 547:137-147

Brodziak J, Link J (2002) Ecosystem-based fishery management: What is it and how can we do it? Bull Mar Sci 70: 589-611

Brusca RC, Brusca GJ (2003) Invertebrates, 2nd edn. Sinauer Associates, Sunderland, MA

Caddy JF (1989) A perspective on the population dynamics 
and assessment of scallop fisheries, with special reference to sea scallop, Placopecten magellanicus (Gmelin). In: Caddy JF (ed) Marine invertebrate fisheries: their assessment and management. John Wiley \& Sons, New York, NY, p 559-589

Carey JD, Stokesbury KDE (2011) An assessment of juvenile and adult sea scallop, Placopecten magellanicus, distribution in the northwest Atlantic using high-resolution still imagery. J Shellfish Res 30:569-582

Chao A, Chazdon RL, Colwell RK, Shen TJ (2005) A new statistical approach for assessing similarity of species composition with incidence and abundance data. Ecol Lett 8: 148-159

Cochran WG (1977) Sampling techniques. John Wiley \& Sons, New York, NY

Collie JS, Escanero GA, Valentine PC (1997) Effects of bottom fishing on the benthic megafauna of Georges Bank. Mar Ecol Prog Ser 155:159-172

Collie JS, Hall SJ, Kaiser MJ, Poiner IR (2000) A quantitative analysis of fishing impacts on shelf sea benthos. J Anim Ecol 69:785-798

Collie JS, Hermsen JM, Valentine PC (2009) Recolonization of gravel habitats on Georges Bank (northwest Atlantic). Deep Sea Res II 56:1847-1855

Colwell RK (2009) Biodiversity: concepts, patterns, and measurement. In: Levin SA, Carpenter SR, Godfray HCJ, Kinzig AP and others (eds) The Princeton guide to ecology. Princeton University Press, Princeton, NJ, p 257-263

Diesing M, Stephens D, Aldridge J (2013) A proposed method for assessing the extent of the seabed significantly affected by demersal fishing in the Greater North Sea. ICES J Mar Sci 70:1085-1096

Gotelli NJ, Colwell RK (2011) Estimating species richness. In: Magurran AE, McGill BJ (eds) Biological diversity: frontiers in measurement and assessment. Oxford University Press, New York, NY, p 39-54

Harris BP, Stokesbury KD (2010) The spatial structure of local surficial sediment characteristics on Georges Bank, USA. Cont Shelf Res 30(17):1840-53

KHiddink JG, Jennings S, Kaiser MJ, Queirós AM, Duplisea DE, Piet GJ (2006) Cumulative impacts of seabed trawl disturbance on benthic biomass, production, and species richness in different habitats. Can J Fish Aquat Sci 63: 721-736

Jennings S, Kaiser MJ (1998) The effects of fishing on marine ecosystems. Adv Mar Biol 34:201-352

Krebs CJ (1989) Ecological methodology. Harper \& Row, New York, NY

* Lambert GI, Jennings S, Kaiser MJ, Davies TW, Hiddink JG (2014) Quantifying recovery rates and resilience of seabed impacted by bottom fishing. J Appl Ecol 51:1326-1336

Langton RW, Bowman RE (1980) Food of fifteen northwest Atlantic gadiform fishes. NOAA Tech Rep NMFS SSRF740

Kangton RW, Robinson WE (1990) Faunal associations on scallop grounds in the western Gulf of Maine. J Exp Mar Biol Ecol 144:157-171

Lincoln RJ, Boxshall GA, Clark PF (1992) A dictionary of ecology, evolution and systematics. Cambridge University Press, Cambridge

Link JS (2005) Translating ecosystem indicators into decision criteria. ICES J Mar Sci 62:569-576

MacDonald AM, Adams CF, Stokesbury KDE (2010) Abundance estimates of skates (Rajidae) on the continental shelf of the northeastern USA using a video survey. Trans Am Fish Soc 139:1415-1420

*Marino MC II, Juanes F, Stokesbury KDE (2007) Effect of closed areas on populations of sea star Asterias spp. on Georges Bank. Mar Ecol Prog Ser 347:39-49

O'Keefe CE, Carey JD, Jacobson LD, Hart DR, Stokesbury KD (2010) Comparison of scallop density estimates using the SMAST scallop video survey data with a reduced view field and reduced counts of individuals per image. Appendix B3, 50th northeast regional stock assessment workshop (50th SAW) assessment report. US Department of Commerce, Northeast Fisheries Science Center, Woods Hole, MA

Oksanen J, Kindt R, Legendre P, O'Hara B and others (2008) The vegan package, Community Ecology Package (Version 1.15-1). http://vegan.r-forge.r-project.org/

Orensanz JM, Parma AM, Iribarne OO (1991) Population dynamics and management of natural stocks. In: Shumway SE (ed) Scallops: biology, ecology and aquaculture. Elsevier, Amsterdam, p 625-713

* Pershing AJ, Alexander MA, Hernandez CM, Kerr LA and others (2015) Slow adaptation in the face of rapid warming leads to collapse of the Gulf of Maine cod fishery. Science 350:809-812

Renkonen O (1938) Statistisch-ökologische Untersuchungen über die terrestrische Käferwelt der finnischen Bruchmoore. Ann Zool Soc Zool Bot Fenn 6:1-231

Sciberras M, Hinz H, Bennell JD, Jenkins SR, Hawkins SJ, Kaiser MJ (2013) Benthic community response to a scallop dredging closure within a dynamic seabed habitat. Mar Ecol Prog Ser 480:83-98

* Shumway SE, Cucci TL, Newell RC, Yentsch CM (1985) Particle selection, ingestion, and absorption in filter-feeding bivalves. J Exp Mar Biol Ecol 91:77-92

* Shumway SE, Bogdanowicz C, Dean D (1988) Oxygen consumption and feeding rates of the sabellid polychaete, Myxicola infundibulum (Renier). Comp Biochem Physiol A 90:425-428

Siegel S, Castellan NJ (1988) The Kolmogorov-Smirnov twosample test. In: Anker JD (ed) Nonparametric statistics for the behavioral sciences, 2nd edn. McGraw-Hill, New York, NY, p 144-151

Stewart BD, Howarth LM (2016) Quantifying and managing the ecosystem effects of scallop dredge fisheries In: Shumway SE, Parsons GJ (eds) Scallops: biology, ecology, aquaculture, and fisheries. Elsevier, Amsterdam, p 585-610

Stokesbury KDE (2002) Estimation of sea scallop, Placopecten magellanicus, abundance in closed areas of Georges Bank. Trans Am Fish Soc 131:1081-1092

Stokesbury KDE, Harris BP (2006) Impact of limited shortterm sea scallop fishery on epibenthic community of Georges Bank closed areas. Mar Ecol Prog Ser 307: 85-100

Stokesbury KD, Harris BP, Marino MC, Nogueira JI (2004) Estimation of sea scallop abundance using a video survey in off-shore US waters. J Shellfish Res 23:33-40

* Stokesbury KD, Carey JD, Harris BP, O'Keefe CE (2010) High densities of juvenile sea scallop (Placopecten magellanicus) on banks and ledges in the central Gulf of Maine. J Shellfish Res 29:369-372

Szostek CL, Murray LG, Bell W, Rayner G, Kaiser MJ (2016) Natural vs. fishing disturbance: drivers of community composition on traditional king scallop, Pecten maximus, fishing grounds. ICES J Mar Sci 73 (Suppl 1):i70-i83 
Thompson C (2010) The Gulf of Maine in context: state of the Gulf of Maine report. Gulf of Maine Council on the Marine Environment, Dartmouth, NS

Thouzeau G, Robert G, Smith SJ (1991) Spatial variability in distribution and growth of juvenile and adult sea scallops Placopecten magellanicus (Gmelin) on eastern Georges Bank (northwest Atlantic). Mar Ecol Prog Ser 74:205-218

Townsend DW, Thomas AC, Mayer LM, Thomas MA, Quinlan JA (2006) Oceanography of the northwest Atlantic continental shelf. In: Robinson AR, Brink KH (eds) The sea, Vol 14. Harvard University Press, Cambridge, p 119-168

Editorial responsibility: Paul Snelgrove,

St. John's, Newfoundland and Labrador, Canada van Denderen PD, Bolam SG, Hiddink JG, Jennings S, Kenny A, Rijnsdorp AD, van Kooten T (2015) Similar effects of bottom trawling and natural disturbance on composition and function of benthic communities across habitats. Mar Ecol Prog Ser 541:31-43

*Weaver JC, Aizenberg J, Fantner GE, Kisailus D and others (2007) Hierarchical assembly of the siliceous skeletal lattice of the hexactinellid sponge Euplectella aspergillum. J Struct Biol 158:93-106

Zar JH (2010) Biostatistical analysis, 5th edn. Prentice-Hall, Upper Saddle River, NJ

Submitted: November 10, 2016; Accepted: March 12, 2018 Proofs received from author(s): May 6, 2018 